\title{
The social production of sacred space in urban Oslo
}

\author{
Enstedt, Daniel \\ University of Gothenburg, Sweden \\ daniel.enstedt@religion.gu.se
}

\begin{abstract}
This article examines two recent expressions of religion in the multi-religious setting of the Norwegian capital Oslo. The Muslim group Ansar al-Sunnah's claim of the district Grønland is scrutinized in relation to the public and cultural image of Islam in Norway, and a Christian response to the contemporary multi-religious context is examined via an analysis of the priest Gyrid Gunnes' performance at The National Exhibition of the Visual Arts in Oslo. These cases are further discussed in relation to spatial theories and theologically embedded questions about ecclesiology and eschatology. This article shows that Ansar al-Sunnah stages an image of Islam that is produced in a cultural Islamophobic discourse, while Gunnes' performance problematizes taken-for-granted notions about God, the church and what it means to be a Christian. The prevailing, dominant and culturally embedded ideas of what it means to be a Christian or a Muslim are being challenged in Gunnes' performance through the use of queer theory and apophatic theology.
\end{abstract}

\section{Keywords}

Urban studies, spatiality, Islam, Islamophobia, Christianity, migration, The Nordic countries, identity politics, queer theory, queer theology

In the beginning was the Topos. Before - long before - the advent of the Logos

Henri Lefebvre, The Production of Space (1991:174)

\section{Introduction}

In August 2012, the Norwegian branch of the Islamist group Ansar alSunnah threatens with an "11 September attack" as well as a more extensive attack than those Anders Behring Breivik carried out in Oslo and on the island Utøya on the 22 July 2011, where he killed 77 people. In addition, the 
group wants to establish an Islamic state in the district Grønland, located in the central parts of Oslo. As Ansar al-Sunnah puts it: "We do not want to be a part of the Norwegian society. And we do not see it as a necessity to move out of Norway, since we were born and raised here. Allah's earth belongs to everyone. But let Grønland become ours." Even though Ansar al-Sunnah is far from representative for Norwegian Islam, their proclamation actualizes several fundamental questions regarding religion, spatiality and the organization of society. After an analysis of Ansar alSunnah's letter and the Muslim situation in urban Oslo, I will examine a Christian response to the present-day multi-religious context expressed by the priest Gyrid Gunnes and her performance at The National Exhibition of the Visual Arts in Oslo. The article continues with a theoretical discussion about religion and spatiality and raises theologically embedded questions about ecclesiology and eschatology in a multi-religious setting.

Even though the Lutheran church of Norway has the majority of the Norwegian population as members and still plays an important part in the cultural and religious year in Norway, immigrant religions, new forms of Christianity and new spirituality - as well as non-religion - have changed the religious and cultural landscape in Norway in recent decades. This ongoing change is not only affecting the cultural and religious ideas of the population at large, but also city-planning, architecture and public behaviour. Nowadays, Oslo is in many ways a postsecular city, that is, as Christopher Baker and Justin Beaumont defines it, "a public space which continues to be shaped by ongoing dynamics of secularization and secularism (and political and cultural ideology) but that also has to negotiate and make space for the re-emergence of public expressions of religion and spirituality" (Baker \& Beaumont 2011a:33). Furthermore, the "re-emergence of public religion in Western urban life, [is] driven primarily by diasporic flows" (Baker \& Beaumont 2011a:33).

The immigration debate in Norway, as in the other Nordic countries, has concerned migration politics, national identity, assimilation, terrorism and hate-crimes. The rise of Islamophobia in Western European countries is aligned with the public discourses about Islam and Muslims due to the

1 All translations from Norwegian are mine. 
emergence of new Muslim communities in these previously Christian countries (Allen 2010). Yet another aspect of this development is related to the so called "new visibility of religion" (Hoelzl \& Ward 2008) where the idea of privatization of religion is challenged by new mosque buildings, religion-related clothing such as the veil in the public sphere, and other religious signs and symbols that have emerged in places that has been understood as "secular" (cf. Gökarıksel 2009; Göle 2004; Woodhead 2009). In Norway, and in the Nordic countries in general, this new visibility of religion has often been associated with Islam, or, to phrase it differently, Islam has become the prototypical form of religion.

\section{Claiming Grønland}

Oslo is one of the wealthiest regions in the world and one of the most ethnically diverse cities in Europe. Many immigrants come from countries such as Pakistan, Somalia, Iraq, Turkey and Morocco where Islam is widely practiced. ${ }^{2}$ However, that does not indicate that all immigrants from Muslim-majority countries are believing or practicing Muslims. The largest Muslim immigrant group in Norway is from Pakistan, followed by groups from Iraq, Somalia and Bosnia-Hercegovina (Rolland 2011). ${ }^{3}$ Most of these groups are located in, or near, the district Grønland in central Oslo.

The former working-class neighbourhood Grønland is a relatively small area located on the east side of town, close to the central station. The recent gentrification of nearby areas makes Grønland even more "exotic" as an alternative district where hipsters, business people and bank personnel can interact. In a 2014 tourist guide two routes were suggested; one to the upper class west side of Oslo and the other, "east walk", that stretches from "hipster parks to multi-culti Grønland". Grønland is described as "packed full of cool little vegetable- and textile shops, halal butchers and more or less dodgy bars. On the way down Motzeldtsgate you'll pass one of Oslo's few Mosques". 4 The phenomenon where parts of a city are themed as religious is not unusual

2 http://www.coe.int/t/dg4/cultureheritage/culture/cities/osloprofile.pdf [Acessed: 2015-02-06]

3 http://folk.uio.no/leirvik/tekster/Religiousstatistics.htm [Accessed: 2015-02-06]

4 http://use-it.unginfo.oslo.no/WP/2014/08/26/the-new-use-it-oslo-map-for-2014/ [Accessed: 2015-02-06] 
in a tourist context, where thematic routs or walks are offered. But as other tourist landscapes, Grønland is at risk of reproducing "well-established exotic, colonial and Orientalist images and discourses" (Stausberg 2011:106). Consuming Grønland, as a tourist, can be seen as what Dean MacCannell (1992) has called cultural cannibalism, that, as Curtis Coats explains it, "refers to tourist activities that appropriate and consume host cultures to fulfil tourist desire" (Coats 2008:484). The point here, however, is not to engage in tourism studies, but instead to draw on some of the perspectives from such research that understand spatiality as socially produced, consumed and reproduced, and as such embedded in power.

Ansar al-Sunnah want the Norwegian state to give them Grønland to "rule entirely by ourselves, with our own ministers, border guards, police and judicial system governed by Sharia law, and prohibit all the evil you stand for and that is contrary to Allah's laws. [...]. We do not wish to live together with dirty beasts like you". In their letter, Ansar al-Sunnah motivates their request by referring to the Norwegian society's "filth and bad values". These values evolve around gender and sexuality and they mention a lack of respect for women since Norwegian society lets the women "strut around half naked". In addition:

You allow the dirty disease homosexuality that is against nature and [even] promote it. Furthermore, you allow the mixing of gender, which only leads to sins. You have family breakdown and illegitimate children as core values, not to mention your extensive use of interest rate loans, alcohol and drugs.

This position against "liberal" values shares some of the perspectives from the so called Christian Right, at least when Doris Buss and Didi Herman describes the American Christian Right as "united in a shared opposition to a perceived 'global liberal agenda,' and, in particular, to 'international feminism' and 'secular humanism'" (Buss \& Herman 2003:xix; see also Herman 1997). Even though the Christian right and Muslim groups as Ansar al-Sunnah are dissimilar in many respects, they seem, at least from one perspective, to be part of a global, religious community of values.

In comparison to the ultra-orthodox Jewish neighbourhood Mea Shearim in Jerusalem several aspects are striking. In Mea Shearim the ultra-orthodox community has put up signs like: "Please do not pass our neighbourhood in 
immodest clothes" (Fenster 2011:72. Original in italics). "Do not disturb"signs like that is, on the one hand, marking the boundaries between the religious neighbourhood and the surrounding areas and, on the other hand, encouraging tourists, as well as more liberal Jews, not to violate the norms and moral codes of the area. Mea Shearim is a popular tourist site where tourists can see and take pictures of "real", "authentic" Jews, with all their attributes. The inhabitants of Mea Shearim are looked upon with what John Urry has called the "tourist gaze" (Urry 1990). Nezar Alsayyad takes Urry's concept a step further when talking about "engazement" as "the process through which the gaze transforms the material reality of the built environment into a cultural imaginary" (Alsayyad 2001:4). Grønland can, following that logic, be seen as a product of engazement, where cultural images of Islam are attributed to the bodies of the inhabitants and to the area itself. Henri Lefebvre's dictum, that space is socially produced and not a given fact has, from a postmodern perspective, got the emphasis on cultural images, the subject's desire and consumption (in a broader sense) as a constitutive part of the social. ${ }^{5}$

Claiming Grønland is also, as in the Mea Shearim case, an expression of frictioned urban space (Jameson 1991). The religious aspect of frictioned space implies that the "urban environment is a battleground for cultural and ideological control" and that "religious identity has profoundly affected the way people view and contest urban space" (Baker \& Beaumont 2011b:258). The spatial aspects and norms are articulated in relation, and in stark contrast, to the surrounding society, and, as in Mea Shearim, Ansar al-Sunnah wants the boundaries to be further marked, not only physically by border guards, but also with a bodily behaviour and practices, cloths, symbols and food, that are in line with their own interpretation of Islam. The spatial aspects of the city are fused together with moral behavior and with the bodies that are living together in the neighbourhood. Ansar al-Sunnah's utopian image of the district Grønland has at least a couple of things in common with the exotifying image produced in the tourist guide to Oslo. When creating a Norwegian Muslim identity, and claiming

5 In fact, Lefebvre himself underscored the importance of understanding the commodification of sites since we "buy on the basis of images" (Lefebvre 1991:76). Urban space is depicted as both "a product and as a work, in the sense in which art created works” (Lefebvre 1991:108). 
central parts of urban Oslo, the Muslim group is activating several of the culturally produced stereotypes of Islam and Muslims that is expressed in public Islamophobic discourse in present-day Norway. In such a public, social imaginary the Muslim community is often portrayed as rigid, masculine, aggressive and anti-modern (Enstedt \& Larsson 2013; Enstedt 2014). While, as Lily Kong describes it,

the intersection of these [racialized, gendered] discourses with reworked Orientalist leanings that construct Islam as antithetical to "western" culture and Muslim women as the embodiment of a 'fundamentalist' and repressive religion [...] young Muslim men's masculinities are shaped by markers of social difference and locality, and thus are multiple and fluid. (Kong 2010:758)

As a result of such an Islamophobic and prejudicial setting "young Muslim people are increasingly defining their identities in terms of their religion, as opposed, for example, to their parental country of origin" (Kong 2010:758). Such a turn to Islam by the second generation Muslims also seems to be the case in Oslo. At the same time it is obvious that the male voice of Ansar al-Sunnah is more in line with the "female" position in the above quote.

Even though urban space has been associated with a turn from religion, where a growing number of ex-Muslims are expressing their views on Islam from the perspective of the apostate, there is also a parallel process in the Nordic countries where second and third generation immigrants from Muslim-majority countries are engaging in their (grand)parents religious heritage. A parallel can be found in Synnøve Bendixsen's study of young second generation immigrant female Muslims' "turn to Islam" in Berlin. In contrast to their parents' generally more distant relationship to religion they were adopting a "true" form of Islam: "the young deem their parents as not observing Islam 'correctly,' but as performing a mixture of religious forms and traditions brought with them from their (Turkish) villages" (Bendixsen 2010:97). Such a "'turn to Islam' is an urban phenomenon" that can be found in other cities such as Cairo, Istanbul and Oslo (Bendixsen 2010:103). Like Berlin (but not Istanbul and Cairo), Oslo is part of a nonMuslim society, where stereotypes and prejudices about Muslims and Islam is part of the conditions for (re-)inventing, negotiating and creating a new Norwegian Muslim identity in the urban space of Oslo. 
Patricia Alleyne-Dettmers examines the construction of a new" black British identity" by looking at the "national identity as presented on the carnival stage at Notting Hill as a public re-enactment of early colonial migrations from the horrors of the colonial legacy" (Alleyne-Dettmers 1997:165). It is the cultural image and public embodiment of "Africa" that is in focus and how it "becomes an imagined community, which is aesthetically realized when it climaxes as a carnival costume on a masquerader dancing through the streets of Notting Hill” (Alleyne-Dettmers 1997:178). Africa, Patricia Alleyne-Dettmers argues, "is not a continent but a concept. [...]. Through this aesthetic, imaginary reconstruction of denigrated African culture powerful symbols belonging to the African continent are moved around the world" (Alleyne-Dettmers 1997:178-179). Returning to Islam in Oslo, and following Alleyne-Dettmers' line of argument, one could say that Islam is in a similar way imagined, constructed and embodied through "costumes" and gestures on the stage of Grønland. Ansar al-Sunnah's threat is furthermore, to use the words of Charles H. Lippy and Eric Tranby "a theatrical form of violence; in other words, it is as a symbolic act. It uses images of a cosmic war between good and evil or martyrdom and is performed to dramatize a cause" (Lippy \& Tranby 2013:202). From such perspective the urban setting is a stage where Ansar al-Sunnah's utopia visions an area governed by Muslims following and embodying Sharia. Otherwise it will, according to the threat, turn into a stage of terror.

Claiming Grønland as a form of sacred area in Oslo is an attempt to make a contemporary urban space - with informal, everyday religious practices of a range of different religious and non-religious traditions Islamic and mono-confessional. Furthermore, Ansar al-Sunnah's demand can be seen as an expression of a "contested place" (Magnussen 2013), but also as a claim for the "right to the city" (Lefebvre 1996), where different religious and non-religious norms, values and practices are expressed side by side, in a symbolically laden place in central Oslo. As Lily Kong puts it: "there are many ways in which every day spaces can be implicated in religious meaning-making, legitimating, maintaining and enhancing, but also challenging religious life, beliefs, practices and identities." (Kong 2010:757). Bodily emotions and practices, together with clothing, food and materiality stands in relation to sacred values, norms and ideals, expressed by religious groups and traditions, and are intertwined with the particular 
setting - its history, architecture and collective memory - of which it is a part. The myriad of parallel meaning-making and the struggle for sacred spaces that is unfolding in urban Oslo is, "despite the official rhetoric of multiculturalism", as Kong puts is, though referring to another context, related to the fact that "sacred spaces are often at the heart of intense contestation, with wider community resistance to the establishment of 'unfamiliar' religious sites or sacred sites of minority groups" (Kong 2010:757). That is, for instance, evident in the cultural Islamophobia and hate crimes against religious minorities in Norway.

\section{Islamophobia, hate crimes and inter-faith dialogue}

Anders Behring Breivik's atrocity in Oslo and on the island Utøya on the 22 July 2011, where he killed 77 people, has become a collective trauma in Norwegian society. In his manifesto 2083: A European Declaration of Independence Breivik mentions the immigration politics and Islam's presence in Norway as motivation factors behind the attacks, as well as a defence of "traditional" Norwegian values where "cultural" Christianity plays an important part. Even though Breivik himself has become a pariah in Norway with only a few, if any, supporters, the views expressed in his manifesto is part of a much wider anti-Muslim rhetoric in contemporary Norway (Bangstad 2014). The Norwegian Defence League (NDL) is, for instance, organizing demonstrations and protests against Islam in Oslo and around Norway. As similar groups in other European countries, NDL wants to "restrict Islamic influence in Norway". ${ }^{6}$ There are also other forms of anti-Muslim rhetoric in other groups and political parties that are expressed in debates about immigration and integration. In addition, the Norwegian society has been witnessing an increased number of hate crimes against Muslim groups and buildings. These kinds of anti-Muslim policies and actions are often based on, what usually is referred to as, an Islamophobic discourse (Bangstad 2014:177-178). In such discourse, Islam is often portrayed in a negative and biased way, as an anti-modern, irrational, and morally corrupt religion, as well as oppressive, misogynist and violent (Enstedt \& Larsson 2013).

6 http://norwegiandefenceleague.com/modules/about/ [Accessed: 2015-02-14] 
In their letter, Ansar al-Sunnah is performing and reproducing the negative, stereotypical image of Islam that is embedded in the Islamophobic discourse. Their demand of taking control over Grønland confirms the worst-case scenario in the anti-Muslim rhetoric, which is that Norway gradually will become a Muslim country if nothing is done about the present situation. Ansar al-Sunnah is also threatening with a terrorist attack, worse than Breivik's, and is thus also activating the image of Islam as violent and primitive. At the same time, Ansar al-Sunnah is counteracting the more liberal Muslims' attempts to have an inter-faith dialogue with representatives of Christianity in Norway.

In his manifesto in True Religion (2003), theologian Graham Ward has prophesied that in the future "the politics of politeness are erased by the radical politics of difference" and that "faith communities might then turn upon each other" (Ward 2003:ix). The problem is, according to Ward, the faith-communities tendency to turn to neo-tribalism and to fetishize their faith:

For both the British Muslims and the British non-Muslims the politics of difference, while calling into question the representations and images of the other, can make it impossible to discuss the 'other' at all [...]. The politics of difference produce, then, both apartheids and paralysis. It can reinforce a ghettoization, rendering us all victims of the way we represent ourselves to each other. We can become products of our own generated mythologies, caught up with the fetishism of faith (Ward 2003:144).

The tendencies to this kind of faith-fetishism and neo-tribalism are, of course, not only the case in Muslim faith-communities in Norway, but also in Christian and other religious communities. Ansar al-Sunnah can indeed be understood as a product of their "own generated mythologies" where the mythological part is not only produced by the group itself, but by the general cultural anti-Muslim and Islamophobic discourse in Norway that is based on the politics of difference. The question is then how to repeal the current situation and the politics of difference.

The more liberal branches of Islam and Christianity in Norway have put a lot of effort into inter-faith dialogue (Leirvik 2001; Leirvik 2006). This is not the place to go through all of the inter-religious initiatives that are going 
on in Oslo, some of them with direct reference to The Oslo Declaration on Freedom of Religion or Belief that sprung out of the International conference on the freedom of religion, held in 1998. But as one typical example, here articulated by the Council for Religious and Life Stance Communities (Samarbeidsrådet for tros- og livssynssamfunn), these inter-faith dialogues have generally the ambition to "promote mutual understanding and respect between different religious and life stance communities through dialogue [and to] work towards equality between various religious and life stance communities in Norway". T The question is, however, if this kind of dialogue, that has been ongoing since the early 1990s, at all has reached its goal. Is the inter-faith dialogue in fact a relatively isolated activity happening in places where "mutual understanding and respect", at least to some extent, already is established?

\section{Christian prayers to Allah}

I want to turn to another strategy concerning spatiality and multireligiosity in Oslo. On Sunday the 14th of September 2014, Gyrid Gunnes, a priest in the Church of Norway, made her first out of four performances at The National Exhibition of the Visual Arts (Kunstnernes hus). In Gunnes' performance at the autumn exhibition, called Prayers to Allah (Bønner til Allah), the artist/priest read her own, and the public's, prayers to Allah on Sundays at 1 PM. Gunnes wore a cassock and was thereby performing as a priest at the exhibition. She is also referring to herself as a priest in the exhibition's program. ${ }^{8}$

From a spatial perspective, the framing of the exhibition is important, not the least since the state of Norway is involved, financing both the exhibition and the Church of Norway. Furthermore, the church and the national exhibition are central institution in Norwegian society and important cultural symbols. The framing of the exhibition is a recognized public space and public institution; the position taken is from the stance of the cultural and religious majority and a relatively privilege positon. How, then, is Gunnes' performance dealing with the questions concerning

7 http://www.trooglivssyn.no/index.cfm?id=136722 [Accessed: 2015-02-15]

8 http://www.hostutstillingen.no/kunstnere-2012/verk/ [Accessed: 2015-01-20]; http://www.nrk.no/ video/PS*172993 [Accessed: 2015-01-20] 
multi-culture and Islam, and how is her performance to be understood from spatial, corporal and theological perspectives?

In the exhibition text Gunnes motivates the performance by recognizing that present-day Norway is a multi-religious society and that "Allah" is the word for God that also Arabic speaking Christians use. The short text is also criticizing "right-wing forces" and the idea that the God of Christianity and the God of Islam are "fundamentally different and have nothing in common" ${ }^{9}$ Gunnes invites the visitors to formulate their own prayers to Allah and to write them down on a blank piece of article with the pre-printed words "Dear Allah". The visitors can pray for themselves, or lay the article in a pot, or put them on the wall for Gunnes to read on the following Sunday. The reason for this is, as Gunnes herself expresses it in the newspaper Dagbladet, that "the audience is given the possibility to explore other ways to relate to Allah than as one which is about the faith of others". ${ }^{10}$ However, on the first Sunday of the performance all prayers were formulated by Gunnes herself. "Dear Allah", the first prayer begins, "I don't know if I believe in you, but now I am praying to you. Friend to friend. Amen."11 There are, of course, theological implications to be drawn, not only from the prayers or the texts, but also from the embodied, ritual performance itself. I will return to these implications shortly.

In a self-reflective prayer, Gunnes refers to her job as a priest in the Church of Norway where she preached about the "fellowship across religions", but in "worship, prayer, praise and thanksgiving were only the Father, Son and Holy Spirit". Part of the prevailing problems in the multi-religious setting is not only the reproduction of seemingly stable traditions, images of belonging and "otherness", but also the ongoing talk between traditions. Such a faith-based, or interfaith, work can thus be contra productive since it affirms certain beforehand given positions. The dialog between religions also articulates the positions even more, and confirms a certain image of what it means, in this case, to be a Muslim or a Christian. Gunnes'

9 http://www.hostutstillingen.no/kunstnere-2012/verk/ [Accessed: 2015-01-20]

10 http://www.dagbladet.no/2014/09/12/kultur/meninger/kronikk/hostutstillingen/religion/35249301/ [Accessed: 2014-11-24]

11 All prayers are published in the Christian newspaper Dagen. See: http://www.dagen.no/ Nyheter/29/09/2014/Her_er_prestens_ti_b\%C3\%B8nner_til_Allah-118500 [Accessed: 2014-10-10] 
performance questions such stable positions by embodying the word "Allah". At the same time she is asking for forgiveness if she in prayer "colonizes others' transcendence".

In an indirect reference to the islamophobia of the West, Gunnes mentions an event in South Africa: "There are people that are afraid that Europe will be a Muslim region. [...] In South Africa, my friends said: Missionaries came with Christianity. But God was already here." Does that indicate that Gunnes' God is one and the same despite the difference between religious traditions? Not necessarily. In the daily Norwegian newspaper Dagbladet Gunnes makes her position clear from the beginning; she does not want to be a Muslim and she does not claim that the Christian and the Muslim God is one and the same. Instead, she wants to challenge what she calls the metaphysical presumptions of religion:

We are accustomed to think that religion and religion's sister atheism start in issues related to metaphysics, as in the following questions: Does God exist? Who is God? Are all gods really the same God? Where is God? In this performance, the question of metaphysics is set aside. My prayers to Allah begin instead of acknowledging the political in all religious language (for instance prayer). ${ }^{12}$

Instead of talking about metaphysics and questions about truth, Gunnes focuses on ethical questions that are related to language. "How can my prayers", Gunnes writes, "contribute to a debate that does not construct Muslims and Islam to be fundamentally different than Christians? How can my language illustrate the complexity and instability of my own religious and cultural tradition - and in others traditions?"

The prayers of Gunnes' also consist of critic of the church, the Christian community and Norwegian society. She raises questions about God, tradition and hope:

Am I praying to you, Allah, or to those who hear these words? Maybe I am praying to one that is not yet born. I pray to the hope that there will be a sentence on the other side of the dot. I pray to

12 http://www.dagbladet.no/2014/09/12/kultur/meninger/kronikk/hostutstillingen/religion/35249301/ [Accessed: 2014-11-24] 
prayer. To the community of all who are praying. I pray to your warm feet. Amen.

Gunnes' prayers raise several theological questions that are related to the Christian tradition and the seemingly clear-cut boundaries between religions.

Gunnes describes her own position as privileged since she represents the majority religion and the Church that for long has been aligned with secular authority in Norway. The inter-faith dialogue that is happening in Norway and elsewhere is mostly about talking about faith; praying, Gunnes stresses, is all about "doing faith". There have admittedly been faith-based activities before, but often of another character. "What happens when religion is expressed as prayer?", Gunnes asks, "Prayer as a genre is a call from an 'I' to a 'you.' It is a form of address that holds thanksgiving, confidence, but also questions, criticism, complaint and rage”.

Developing religious practices and languages for a multi-cultural setting is, Gunnes argues, "a profoundly liberal project", not least since "it goes beyond the authorized religious language and space". The reason to why Gunnes chose an art room, and not a church, a mosque or a synagogue, is that a traditional sacred room would make the performance more familiar to those who are accustomed with the traditional religious language and practices. Such position indicates however that Gunnes understands the space of the art exhibition as more neutral than the other places mentioned. This is also articulated when Gunnes discusses the context of the exhibition as a suitable place to "try out liberal, non-authorized and experimental ways to challenge religious tradition and language, but that is not aggressive or wishes to contribute to a confrontational identity politics that cements differences and increases stigma". The performance cannot be reduced to be either religion or art, Gunnes argues: "By being both, the performance explores the shift that occurs when a religious expression like prayer comes out of its religiously authorized space as a guest in a secular space." The ambiguity that Gunnes strives for is aligned with a specific hope, namely that "such a shift of body, practice and rooms open up to new metaphors and actions - perhaps also new experiences of holiness". This is also expressed in an interview on the public television NRK where Gunnes put emphasis on the exploration of the boundaries between the secular and 
holy room. Such a practice is, in Gunnes view, actually right at the heart of what it means to be a Christian: "One of the core of Jesus' proclamation was to dare to go across borders. [...]. So this [performance] is an extension of my ordination promise and my ministry as a Christian priest". ${ }^{13}$

The fifth prayer raises questions about the naming of God and rules and norms, not only within Christian tradition but also within other religious traditions.

Dear Allah. I am probably not praying to you in a correct manner. I should call you "almighty", "lord" and "exalted". I know that you gods like that. I have learnt that in church. But I will not use such adjectives. [...] Allah, I have too much respect for your maybeexistence to degrade you to be an enlarged version of the earthly language. Amen.

This prayer indicates that Gunnes relies upon an apophatic theology that is aligned with queer theology, where the destabilization of God, tradition, practices and the authority of the Church is at the forefront. Queer theology has, as queer theory at large, been upheld with issues concerning gender and sexuality, even though these issues relate to other central theological questions concerning ecclesiology, eschatology, incarnation and biblical authority (Loughlin 2007; Althaus-Reid 2003; Cheng 2011). Patrick S. Cheng's description of the four marks of queer theory alludes to the four marks of the church (cf. Thatcher 2011:135-153). Both the church and queerness is, according to Cheng, "a fluid body of ideas that is constantly in the process of becoming” (Cheng 2015:155). These four marks' expression in queer theology gives a frame to interpret Gunnes' performance, which also indicates a shift in queer theology itself, from focusing on gender and sexuality to engage in other issues such as the construction of "stable" religious identities in inter-faith dialogue.

The first of the four marks is, following Cheng, identity without essence, which is connected to apophatic or negative theology and the naming of God. Gunnes' performance is naming God, but in the "wrong" way, and by doing so it reveals the ambiguity and instability of naming God. The second mark is transgression: "Christian theology is fundamentally queer to the

13 http://www.nrk.no/kultur/ber-til-allah-pa-hostutstillingen-1.11927667 [Accessed: 2015-02-01] 
extent that it transgresses and challenges the world's religious, political, and sexual norms" (Cheng 2015:161). Gunnes is indeed transgressing the traditional and established boundaries of religions by mixing Islam and Christianity together, although not in a clear way since she is relating to Allah as a way for Arabic speaking Christians to refer to God. The transgression also has spatial aspects; the performance is done outside a religious institution, but with a religious language, practice (prayer) and clothing (the cassock); Gunnes is acting as a priest at the exhibition.

The third strand of queer theology mentioned by Cheng is resisting binaries. This mark is illustrated by Cheng's book Radical Love (2011), where he describes radical love as "a love so extreme that it dissolves our existing boundaries” (Cheng 2011:x). These boundaries do not only concern male/female and heterosexual/homosexual, as Cheng puts it in another text: "Christian theology deconstructs the binary of divine/ human” (Cheng 2015:162). Cheng portrays Jesus Christ as a "'boundarycrosser extraordinaire', whether this relates to 'divine, social, sexual, or gender boundaries"' (Cheng 2011:79). In her performance, Gunnes resists the binaries between Christian/Muslim, we/them, and us/the other. Such a subversive move can from critics be seen as a move away from Christianity, but as Cheng argues, it can also be understood as an articulation of one of the central aspects of Christianity. Another theological question, relating to queer theology and Gunnes' performance, concerns the concept of sin. Bystanding, choosing not to act, can, according to Cheng, "be understood as exhibiting the sin of conformity", that is passively confirming the status quo (Cheng 2012:101-110; Cheng 2015:161).

The fourth and final mark of queer theology is social construction that holds that "earthly identities - whether secular or religious - are actually not of ultimate significance, particularly from an eschatological perspective" (Cheng 2015:163). The emphasis in this last mark is on how Christian tradition has constructed not only sexual, but also other types of religious identities. What is interesting here is, as I have pointed out above, how Gunnes' performance shifts focus from "sexuality" to "religiosity", but, theoretically speaking, from the same stance. 


\section{Heterotopia, utopia and beyond}

In the short essay "Different Spaces" (Des Espace Autres; could also be translated as Of other spaces), from a lecture held in 1967, but not published until 1984, Michel Foucault discusses the term heterotopia, that came to be a central term in fields like geography, architecture and cultural studies. "We are in an age", Foucault states in 1967, "when space is presented to us in the form of relations of emplacement" (Foucault 1998:177). That means, Foucault explains further, that "we live inside an ensemble of relations that define emplacements that are irreducible to each other and absolutely nonsuperposable" (Foucault 1998:178). In relation to the present-day focus on space, which has replaced the nineteenth century's focus upon history and time, Foucault makes a distinction between utopias, that "are spaces that are fundamentally and essentially unreal", and heterotopias, "actually realized utopias in which the real emplacements, all the other real emplacements that can be found within the culture are, at the same time, represented, contested and reversed" (Foucault 1998:178). The heterotopia is a place that is related to the other parts, places and spaces of society but, in one way or another, displacing those parts. One of the examples given is the organization of bodies in a cemetery which stands in relations to how the lived bodies of the rest of society are situated. The dead bodies of the cemetery are mirroring, another metaphor used by Foucault, the living bodies of the city and reminds the living of their dead relatives and their own upcoming death. The cemetery is the "other city' where each family possessed its dark dwelling” (Foucault 1998:181). A migration situation can be understood in a similar way as the cemetery, when it is marked by an absolute, clear break and a "loss of life" that previously was constitutive for the individual.

The heterotopia can thus be seen as a break with the ordinary, similar to the medieval carnival, but at the same time functions in relation to the other spaces of society, as a constitutive part. Different spaces can simultaneously take place in heterotopia, like in a modern museum, library or vacation resort; a kind of liminality is at the heart of heterotopian place. Heterotopias also have a "function in relation to the remaining space", as either "the role of creating a space of illusion that denounces all real space" or "creating a different space, a different real space as perfect, as meticulous, as wellarranged as ours is disorganized, badly arranged, and muddled" (Foucault 
1998:184). While the former is an example of the heterotopia of illusion, the other is given as an example of the heterotopia of compensation. In the case of Norwegian Islamist group Ansar al-Sunnah's claiming of Grønland it is an expression of the heterotopia of compensation, even though it could be seen as an expression of a utopia of compensation, since there is not a homogenous place but rather a contested place where some inhabitants embody, or tries to embody and materialize, the utopia of Ansar al-Sunnah. That indicates that the heterotopia is activated in several different ways, as compensation and in a liminal place, with several different regimes happening simultaneously.

Henri Lefebvre's well-known spatial triad of perceived (spatial practice), conceived (representations of space) and lived space (representational spaces) has also been influencing the theoretical discussion about social space since the 1970s (Lefebvre 1991:38-39). ${ }^{14}$ While Lefebvre put emphasis on the dialectical relations between the spatial aspects, Edward Soja rebranded Lefebvre's spatial triad, in his 1996 book Thirdspace, into what he calls "trialectics of spatiality", i.e. first, second and third space (Soja 1996:64). It is especially the third space, or what Lefebvre calls lived space, that is of interest here since it is potentially both subversive and creative counter space: "spaces of resistance to the dominant order arising precisely from their subordinate, peripheral, or marginalized positioning" (Soja 1996:68). Ansar al-Sunnah articulate their spatial vision from such marginalized position, but, as Lefebvre puts it: "The idea of a new life is at once realistic and illusory - and hence neither true nor false. [...] the preconditions for a different life have already been created [...] the space which contains the realized preconditions of another life is the same one as prohibits what those preconditions make possible" (Lefebvre 1991:189190). "A total revolution", Lefebvre continues, "seems to be in the offing, as though already immanent to the present. To change life, however, we must first change space." (Lefebvre 1991:190). Claiming Grønland, no matter

14 In The Location of Religion (2005) Kim Knott examines Lefebvre's spatial theory from the perspective of religious studies. "Sacred space not the stimulus for ritual", Knott argues, "ritual, as sacred-making behaviour, brings about 'sacred' space" (Knott 2005:43). In line with such a perspective Knott, following the work of Veikko Anttonen and Jonathan Z. Smith, understands religion as "a consequence of spatial practice, though it is the attribution of meaning that gives such practice its character as "religious"' (Knott 2005:43). 
how absurd the demand might be seen, is, from a Lefebvreian perspective, a claim for a new life from the given conditions in Oslo. It is to challenge the prevailing dominant order by a spatial revolution, and as an effect of such request the hegemonic order is made more visible.

The issue of power in an urban setting is not only a question about materiality and environment, but also about the body, the subject and social reproduction. Banu Gökariksel understands "the body as the most intimate space where religion is lived (or not) and contributes to understanding subjectivity's production through the body" (Gökariksel 2009:669). A central aspect of sacred and religious spaces and sites in urban Oslo has to do with the bodies of the inhabitants. The idea of the body as embedded in geopolitically situated discourses and practices encapsulates a critique against any idea of the body as 'naked', or 'given'. The view of the body itself as a site of power struggles, contested interests and, at the same time, a bearer of symbolic meaning and a central node in the reproduction of power, is closely linked to Michel Foucault's ideas of bio-politics and the production of knowledge and space (Foucault 1990:140). From such a theoretical standpoint the human body is a part of a religious, cultural and ideological discourse where statements and fundamental assumptions about the sacred are to be found. According to Elizabeth Grosz in Volatile Bodies (1994), such a perspective postures that bodies

are fictionalized, that is, positioned by various cultural narratives and discourses, which are themselves embodiments of culturally established canons, norms, and representational forms, so that they can be seen as living narratives, narratives not always or even usually transparent to themselves (Grosz 1994:118).

This does not mean, as Graham Ward correctly points out, that the body is "tabulae rasae that receive cultural inscriptions"; rather that we do not have immediate access to what may be seen as the most intimate and private parts of ourselves (Ward 2004:74). The body is, to borrow the words of Ola Sigurdson, "not given as a naked fact or phenomenon, but instead intertwined with different theological interests and ideas" (Sigurdson 2006:24). These different interests and ideas can also lead to conflicts and contradictory views, as the ones apparent in urban Oslo. Let me once more turn to Gunnes' performance to discuss the body and spatiality. 
Gunnes wore a cassock and performed as a priest at the exhibition. However, when the Dean of Oslo, Anne-May Grasaas, commented the performance and Gunnes' role as a priest - after critical reactions to the exhibition and a vivid and affective public debate - she made clear that, in this case, Gunnes was an artist rather than a priest, and that the performance was taking place outside the Church. By doing so the dean was able to state that "it is not the church's role to dictate or censure art". ${ }^{15}$ The dean reproduces a modern understanding of the church as belonging to a separate sphere in society with specific roles to fill.

The dean's comment on Gunnes' performance does not only raise ecclesiological questions about the nature and boundaries of the church, but also about the clear-cut sorting of the religious and the secular. That kind of sorting is explicable from Jonathan Z. Smith's discussion about the spatiality of religion and the three spatial categories here, there and anywhere. While religion here is associated with family, domestic and private spheres of society, religion there is the public, official religion aligned with a state sanctioned religion and its temple or church. Religion anywhere oscillates between the other spheres and covers religious activities that are not given room in public religious life or at home, as for instance in other types of religious gatherings and practices (Smith 2004:325334). By locating Gunnes' performance to a space outside the Church of Norway, from religion there to religion anywhere, and by categorizing it as "art", the dean can take her hand of it and, at the same time, misses the opportunity to reflect theologically on the performance. Gunnes' performance does however raise theological questions about ecclesiology, and her performance is destabilizing both an established Christian position and the role of the priest by evoking ambiguity and uncertainty, into the seemingly stable categories Christian and Muslim, Islam and Christianity. But Gunnes is not destabilizing Christianity and Islam as such. She is rather using the stereotypical images of the two religious traditions to transgress the boundaries between them. This is equivalent of to how Judith Butler talks about the drag performance, where the queering of the categories "men" and "women" made use of the same categories to show them to be "empty" (Butler 1999:174-180). Even though Gunnes'

15 http://www.verdidebatt.no/debatt/cat12/subcat13/thread11524630/\#post_11524630 [Accessed: 2014-11-24] 
position is not marginalized in accordance with Soja's Thirdspace, she is challenging the dominant order that defines "us" as Christians or Muslims, and is defining the separate spheres of modern society. Such action might bear the possibility of "radical openness and teeming imaginary", as Soja puts it (Soja 1996:68). Baker and Beaumont points out Soja's concept of the "real-and-imagined" city as important for "theological visions of change and transformation held by several religious groups" (Baker \& Beaumont 2011b:262). However, even though Gunnes' performance/ritual opens up possibilities for the future, the question about actual change remains. I will return to that question shortly.

\section{Theological aftermath}

In Gender Trouble, Judith Butler states "[t]he task is not whether to repeat, but how to repeat or, indeed, to repeat and, through a radical proliferation of gender, to displace the very gender norms that enable the repetition itself" (Butler 1999:189). According to Butler it is the "radical proliferation" that is the key to destabilize and change hegemonic norms and roles. When Gunnes is blending Christian and Muslim elements together in praying to Allah it can be understood accordingly. There is also an ambiguity in her performance since Allah also is used in Christian circles around the world, and the performance is happening "outside" the church. ${ }^{16}$ However, the question about change still remains. Steve Garlick argues that Butler's theory "fails to move beyond the formation and reiteration of the gendered subject, and thus does not attend sufficiently to the agency of that which is withheld from the subject in the constitution of identity" (Garlick 2002:866). Garlick's critique of Butler is articulated from a psychoanalytical perspective. Another, similar but theologically grounded critique, is found in Sarah Coakley's Powers and Submissions (2002) where she points out the lack of an eschatological perspective in Butler's theory. According to Coakley, that is the reason to why Butler's theory fails to challenge the hegemonic gender norms (Coakley 2002:159). The eschatological perspective that Coakley suggests is profoundly aligned with the concept

16 The performance can thus cause a feeling of disgust, or what Julia Kristeva would call abjection, since what is "familiar" is presented in an unfamiliar context or way (Kristeva 1982). 
of death in Christian theology. Such eschatological perspective is further developed by queer theologian Elizabeth Stuart:

Repetition with a critical difference is how the Church performs. It is how it interacts with culture, it is how it keeps itself open to the renewal of the Holy Spirit. And this performance begins in death. Christians die, but that is all they do for death; they are not consumed by death, they die to enter life. (Stuart 2004:67)

In Stuart's perspective, it is death that bears the possibilities not only to destabilize the dominant order of gender and sexuality norms and other differencing variables, but also the possibility to leave "the life of constructed identities for a new type of belonging determined only by God" (Stuart 2004:59-60).

In The Church Faces Death (1999), Michel Jinkins discusses ecclesiology from an eschatological perspective. Instead of formulating yet another taxonomy of what the church is, can or should be - what Nicholas M. Healy has called "blueprint ecclesiologies" (Healy 2000:52) - Jinkins puts forth the concept of death in Christian theology as a destabilizer of such taxonomies and artificial categories. Jinkins formulates his negative, apophatic ecclesiology with support from Jacques Derrida's The Gift of Death (1995) and his characteristic version of a messianic eschatology: "What has not yet arrived at or happened to Christianity is Christianity" (Derrida 1995:28). Derrida refers to the messianic eschatology that claims that Christianity is inevitably incomplete as long as the eschatological promise of Christ's return remains. What does such messianic eschatology have for Jinkins ecclesiology?

The church should meet death in uncertainty, according to Jinkins: "the church can only know this power [of resurrection] in actually facing its death" (Jinkins 1999:14). Christian belief in resurrection after death must be implemented even at the institutional level in the church. The risk of lapsing into different strategies to get the church to survive at all costs is that the aspect of the Christian faith that is about death and resurrection may be marginalized. ${ }^{17}$ Rather than clinging on to ecclesiological ideas,

17 The modern discourse on death and its theological background has a long history. The position of death in contemporary theology can be traced back to thinkers such as 
that are aligned with the Church's institutional character, Jinkins argues that the church could, instead of becoming thanatophobic (afraid of death), be reformed in fundamental ways when its raison d'etre is questioned. The church should, in other words, deal with its thanatophobia, rather than trying to maintain an organization and structures that are doomed to perish. The fear and anxiety of death must be exchanged to belief in death and resurrection (Jinkins 1999:9-14). Or as Stuart puts it: "Death and resurrection are written on the bodies of Christians. [...] Christian queer death by embracing it" (Stuart 2004:63). However, the question about what implications a queer theological perspective can have when applied to a multi-religious situation as the one in present-day Oslo remains.

This article has examined two recent expressions of religion in the multireligious setting of the Norwegian capital Oslo. The Muslim group Ansar al-Sunnah's claim of the district Grønland has been scrutinized in relation to the public and cultural image of Islam in Norway, and a Christian response to the contemporary multi-religious context has been examined via an analysis of the priest Gyrid Gunnes' performance at The National Exhibition of the Visual Arts. I have argued that Ansar al-Sunnah stages an image of Islam that is produced in a cultural Islamophobic discourse, and that Gunnes' performance problematizes ingrained and taken-for-granted notions about God, the church and what it means to be a Christian. However, it does not suggest another new religious identity; instead it manifests an alternative way to relate to the existing hegemonic categories of religion, in this case Christianity and Islam. The prevailing, dominant and culturally embedded ideas of what it means to be a Christian or a Muslim are being challenged, but in an ambiguous way, by the use of queer theology and apophatic theology. ${ }^{18}$ The dominant Christian discourse is intact, from

Kierkegaard, Heidegger and Bultmann, and a recent expression of this discourse in to be found in queer theology. However, this is not the place to conduct an exhaustive genealogy of the different perspectives on death in Christian theology.

18 Such a metaphorical perspective on death can be criticized from other perspectives where death denotes an actual, bodily death, as is the case in, for instance, Breivik's atrocity, or in the death threat of Ansar al-Sunnah. In Gunnes' performance, death is closely aligned with contemporary queer theory where death often is theorized in relation to culture, language and identity (gender, sexuality, etc.). However, that does not mean that actual death is set aside totally, but rather that death understood and discussed from another theoretical standpoint. 
Jinkins' perspective, because of a cultural and religious thanatophobia and an inability to consider the importance of death to Christian belief and theology. A change of the current situation would, however, demand an exhaustive rethinking of ecclesiology and Christian practice from an eschatological perspective. But how that can be implemented in practice remains to be seen and is outside the scope of this article.

\section{Bibliography}

Allen, Christopher 2010. Islamophobia. Farnham, Surrey: Ashgate. Alleyne-Dettmers, Patricia 1997. "'Tribal Arts'. A Case Study of Global Compression in the Notting Hill Carnival," in Eade, John (ed). Living in the Global City. Globalization as a local process. London \& New York: Routledge.

AlSayyad, Nezar 2001. "Global Norms and Urban Forms in the age of Tourism: Manufacturing Heritage, Consuming Tradition," in AlSayyad, Nezar (ed), Consuming Tradition, Manufacturing Heritage: Global Norms and Urban Forms in the Age of Tourism. New York: Routledge.

Althaus-Reid, Marcella María 2003. The Queer God. London: Routledge.

Baker, Christopher Richard \& Beaumont, Justin 2011a. "Postcolonialism and Religion: New Spaces of 'Belonging and Becoming' in the Postsecular City", in Baker, Christopher Richard \& Beaumont, Justin (ed.), Postsecular Cities: Space, Theory and Practice. London: Continuum.

Baker, Christopher Richard \& Beaumont, Justin 2011b. "Afterword: Postsecular Cities", in Baker, Christopher Richard \& Beaumont, Justin (ed.), Postsecular Cities: Space, Theory and Practice. London: Continuum.

Bangstad, Sindre 2014. Anders Breivik and the Rise of Islamaphobia. London: Zed Books. 
Bendixsen, Synnøve 2010. "Islam as a New Urban Identity? Young Female Muslim Creating a Religious Youth Culture in Berlin", in Bonifacio, Glenda Tibe \& Angeles, Vivienne SM (ed.), Gender, Religion, and Migration: Pathways of Integration. Lanham: Lexington Books.

Buss, Doris \& Herman, Didi 2003. Globalizing Family Values: The Christian Right in International Politics. Minneapolis: University of Minnesota Press.

Butler, Judith 1999 [1990]. Gender Trouble: Feminism and the Subversion of Identity. New York: Routledge.

Cheng, Patrick S 2015. "Contribution from Queer Theory," in Thatcher, Adrian (ed), The Oxford Handbook of Theology, Sexuality, and Gender. New York: Oxford University Press.

Cheng, Patrick S 2012. From Sin to Amazing Grace: Discovering the Queer Christ. New York: Seabury Books.

Cheng, Patrick S. 2011. Radical Love: An Introduction to Queer Theology. New York: Seabury Books.

Coakley, Sarah 2002. Powers and Submissions: Spirituality, Philosophy and Gender. Oxford: Blackwell.

Coats, Curtis 2008. "Is the Womb Barren? A Located Study of Spiritual Tourism in Sedona, Arizona, and its Possible Effects on Ecoconsciousness," in Journal for the Study of Religion, Nature and Culture, 2(4):483-507.

Derrida, Jacques 1995. The Gift of Death. Chicago: University of Chicago Press.

Enstedt, Daniel 2014. ”Naeemas dröm. Självbiografiskt stoff och kvinnliga apostaters islamkritik på nätet," in Sjöberg, Maria (ed), Personligt talat: Biografiska perspektiv i humaniora. Göteborg: Makadam.

Enstedt, Daniel \& Larsson, Göran 2013. "Telling the Truth about Islam? Apostasy Narratives and Representations of Islam on WikiIslam.net," in CyberOrient 7:1. 
Fenster, Tovi 2011. "Non-Secular Cities? Visual and Sound Representations of the Religious-Secular Right to the City in Jerusalem" in Baker, Christopher Richard \& Beaumont, Justin (ed), Postsecular Cities: Space, Theory and Practice. London: Continuum.

Foucault, Michel 1998. Essential Works of Foucault, 1954-1984. Vol. 2, Aesthetics, Method and Epistemology. New York: New Press.

Foucault, Michel 1990. The History of Sexuality. Vol. 1, The Will to Knowledge. Harmondsworth: Penguin.

Garlick, Steve 2002. "Melancholic Secrets: Gender Ambivalence and the Unheimlich", in Psychoanalytic Review, 89:6, 861-876.

Grosz, Elizabeth 1994. Volatile Bodies: Toward a Corporeal Feminism. Bloomington: Indiana Univ. Press.

Gökarıksel, Banu 2009. "Beyond the Officially Sacred: Religion, Secularism, and the Body in the Production of Subjectivity," in Social \& Cultural Geography, 10:6, 657-674.

Göle, Nilüfer 2004. Islam in Sicht: der Auftritt von Muslimen im öffentlichen Raum. Bielefeld: Transcript.

Healy, Nicholas M 2000. Church, World, and the Christian Life: Practicalprophetic Ecclesiology. New York: Cambridge Univ. Press.

Herman, Didi 1997. The Antigay Agenda: Orthodox Vision and the Christian Right. Chicago: University of Chicago Press.

Hoelzl, Michael. \& Ward, Graham (eds) 2008. The New Visibility of Religion: Studies in Religion and Cultural Hermeneutics. London: Continuum.

Jameson, Fredric 1991. Postmodernism, or, the Cultural Logic of Late Capitalism. London: Verso.

Jinkins, Michael 1999. The Church Faces Death: Ecclesiology in a Postmodern Context. New York: Oxford University Press.

Knott, Kim 2005. The Location of Religion: A Spatial Analysis of the Left Hand. Oakville: Equinox Pub. 
Kristeva, Julia 1982. Powers of Horror: An Essay on Abjection. New York: Columbia University Press.

Lefebvre, Henri 1996. Writings on Cities. Cambridge: Blackwell.

Lefebvre, Henri 1991. The Production of Space. Oxford: Basil Blackwell.

Leirvik, Oddbjørn 2006. Islam og kristendom. Konflikt eller dialog? Oslo:

Pax.

Leirvik, Oddbjørn 2001. Religionsdialog på norsk. Oslo: Pax.

Lily Kong, 2010. "Global Shifts, Theoretical Shifts: Changing Geographies of Religion," in Progress in Human Geography, 34:6, 755-776.

Lippy, Charles H \& Tranby, Eric 2013. Religion in Contemporary America. New York: Routledge.

Loughlin, Gerard (ed) 2007. Queer Theology: Rethinking the Western Body. Oxford: Blackwell.

MacCannell, Dean 1992. Empty Meeting Grounds: The Tourist Papers. London: Routledge.

Magnussen, Anne (ed) 2013. Contested Places. Odense: University Press of Southern Denmark.

Rolland, Asle 2011. Statistikk om religion, tro og livssyn- en behovsanalyse. Oslo \& Kongsvinger: Statistisk sentralbyrå.

Sigurdson, Ola 2006. Himmelska kroppar: inkarnation, blick, kroppslighet. Göteborg: Glänta.

Smith, Jonathan Z 2004. Relating Religion: Essays in the Study of Religion. Chicago: University of Chicago.

Soja, Edward 1996. Thirdspace: Journeys to Los Angeles and Other Realand-Imagined Places. Malden: Blackwell Publishers.

Soja, Edward W 1989. Postmodern Geographies: The Reassertion of Space in Critical Social Theory. London: Verso.

Stausberg, Michael 2011. Religion and Tourism: Crossroads, Destinations, and Encounters. New York: Routledge. 
Stuart, Elizabeth 2004. "Queering Death," in Althaus-Reid, M \& Isherwood, L (eds), The Sexual Theologian: Essays on Sex, God and Politics. London \& New York: T \& T Clark International.

Thatcher, Adrian 2011. God, Sex, and Gender: An Introduction. Chichester, West Sussex: Wiley-Blackwell.

Urry, John 1990. The Tourist Gaze: Leisure and Travel in Contemporary Societies. London: Sage.

Woodhead, Linda 2009. “The Muslim Veil Controversy and European Values”, in Svensk missionstidskrift, 97:1, 89-105.

Ward, Graham 2004. "On the Politics of Embodiment and the Mystery of All Flesh", in Althaus-Reid, M \& Isherwood, L (eds), The Sexual Theologian: Essays on Sex, God and Politics. London \& New York: $\mathrm{T} \& \mathrm{~T}$ Clark International.

Ward, Graham 2003. True Religion. Oxford: Blackwell. 